\title{
EFFECT OF QUALITY ASSURANCE DEFICIT ON MARKET COMPETITIVENESS FOR EXPORT COMMODITIES AND HOUSEHOLD INCOME IN NIGERIA
}

\author{
Kassim Adekunle Akanni \\ Department of Agricultural Economics \& Farm Management \\ Olabisi Onabanjo University,Ago-Iwoye,Nigeria \\ E-mail:akannikunle2003@yahoo.co.uk
}

\begin{abstract}
The Nigerian's agricultural sub-sector contributes about 37 percent of her Gross Domestic Product (GDP) and employs about 65 per cent of the adult labour force. It is thus the major source of food and fibre for the nation. However, there are increasing concerns about the quality and level of safety of many of the agricultural export commodities, particularly in the European markets due to the composition of high level of unauthorized pesticides. This is a major challenge to the level of market competitiveness for these commodities in the international markets. This study therefore examined the effect of quality assurance deficit on market competitiveness and household income levels. Trends in Nigeria's agricultural export trade between 1980 and 2014 were examined and emphasis was placed on cowpea, dried maize, melon seeds and palm oil. Descriptive and qualitative statistical methods were used to analyze the data. Quantitative statistics included the use of econometric models. Results indicated that there was an increase in the general price level of the commodities at the international market over time. The aggregate market demand for each of them dropped sharply in the last one decade even when the market price per unit increased steadily. This negatively affected the households' average income level as returns on sales of export commodities declined. Huge quantities of the commodities were then forced to be sold at the local markets at cheaper prices. This development negatively affects the consumptions patterns of the exporters as they now have reduced disposable income. Appropriate agencies of government need to be awake to their responsibilities of assessing and certifying the quality of the Nigerian agricultural commodities before exporting them abroad. This will help to further boost the level of consumer confidence in these export commodities especially at the international markets.
\end{abstract}

Keywords: Agricultural Export Commodities, Household Income, Market Competitiveness, Quality Assurance Deficit. (JEL Classification: Q13)

\section{INTRODUCTION}

Nigeria's agricultural sub-sector is the largest contributor (88\%) to the non-oil foreign exchange earnings. Development in the sub-sector is therefore capable of bringing about a broadbased economic growth that is characterized by increased per capita income, reduction in poverty and expansion of employment opportunities. Some of the major agricultural export commodities are cotton,maize, groundnut, hides and skin, beniseed,cocoa,palm produce,rubber and timber, among others(Olukosi and Isitor,1990;NBS,2002;NBS,2009). To compliment local supply, Nigeria imports poultry products (such as chicken and turkey) and processed foods mostly from European countries. Other food imports include canned beef and frozen fish (such as tilapia, mackerel, bonga and stock fish), wheat and fruits and canned juice among others. Huge quantities of these commodities however find their ways into the Nigerian markets through illegal (unofficial) channels. Hence they are often regarded as part of Nigeria's unorthodox trading activities since they do not enter the official transactions of the government. International trading is necessary in order to balance the trade position with Nigeria's trading partners. However, there are increasing concerns on the level of safety of these export and import commodities. For example, just recently, the Nigerian government started enforcing the ban on imported poultry products and frozen fish before they find their ways into the domestic market. This decision was premised on the claims by the Nigeria's Ministry of Agriculture 
that a large proportion of these imported commodities harbor harmful parasites, bacteria,viruses, chemicals or radioactive substances. In a similar vein, the European Union recently suspended some agricultural food exports from Nigeria. These food items include beans (cowpeas), sesame seeds, melon seeds, dried fish and meat, peanut chips and palm oil. Reasons for the suspension are hinged on the allegations that the items constitute danger to human health because they contain a high level of unauthorized pesticide. For instance, the European Food Safety Authority observed that the beans from Nigeria contain between $0.03 \mathrm{mg}$ per kilogramme to $4.6 \mathrm{mg}$ per kilogramme of dichlorovos pesticides when the acceptable maximum residue limit is $0.01 \mathrm{mg} / \mathrm{kg}$.

Again, in 2013, about 24 of the Nigerian agricultural export commodities were rejected from the United Kingdom and the number increased to 42 food products in 2014. Some of these items were said to have been contaminated by aflatoxins. This makes them unfit for human and animal consumption. The health risk that is associated with the consumption of the imported commodities is further heightened due to the relative market competitiveness and preference they enjoy among Nigerian consumers most of whom care less about the chemical composition and possible health implications (such as cancer, skin irritations, internal organs defect and migraine headaches).These imported food products are ironically cheaper than the locally produced food items; thus putting the latter into some market demand risks and uncertainties. This development has remained a source of worry and concern to the local producers of these food products hence they have often called on the Nigerian government to properly address the situation by reversing the ugly trends.

\subsection{Literature Review and Theoretical Framework}

Before the discovery of crude oil in commercial quantities in Nigeria, the agricultural sub-sector was the chief foreign exchange earner constituting between 65-70 per cent of the Gross Domestic Product (GDP) (Olayemi,1980 and Adeyokunnu,1980;CBN,2006).Some of the major agricultural export commodities include cowpeas, sesame seeds, melon seeds, dried meat and fish, peanut chips,palm produce (kernel and oil),kolanut,cashew nuts and foodgrains (such as millet, maize and sorghum),among others (Olukosi and Isitor,1990;Adekanye,1988; Helleiner,1988; CBN,2006 and NBS, 2009). According to Adeyokunnu (1980) and Olatunbosun and Olayide (1980), the marketing of agricultural export crops and the marketing board system dominated the business space in the early period of the nation's post- independence in 1960. The basic intention of the government then was to stabilize producer prices, conduct market research and development and to accumulate the trading surpluses. Between 1955 and 1951,the marketing boards accumulated reserves totalling N43.6 million (Helleiner,1988) and they operated successfully in the Nigeria's agricultural crop marketing space until 1986 when they were proscribed by the Federal government for alleged professional inefficiency and mistrust.

Today, the marketing and distribution of the bulk of agricultural products are in the hands of private individuals and co-operative societies (Adekanye,1988).Again, some acts of corruption bordering on adulteration, distortion of measuring apparatus and poor product qualities now characterize the marketing of agricultural export commodities.Perhaps, the most disturbing implication of this scenario is the recent ban of 42 Nigeria's agricultural food products from the European Union (EU) markets for alleged non-compliance with the minimum quality standards. Some of the affected food products were said to have been contaminated by aflatoxins, making them unfit for human and livestock consumption. This development has grossly affected the level of competitiveness of the Nigeria's agricultural export products, particularly at the international markets (NEPC,2015). It has again negatively affected the household income levels of the farming households in the past months (CBN,2015). It therefore becomes imperative for all exporters of agricultural products in Nigeria to adhere to the global standards (international best practices) in food product exports, especially on quality assurance.

\subsection{Objectives of the study}

The broad objective of this study is to examine the level of market competitiveness for selected agricultural commodities and farmers' household income. Specifically, the study;

a) Investigated the level of market competitiveness and consumer preference for selected internationally traded food products in Nigeria.

b) Established the existing relationship between the level of quality assurance deficit of export commodities, market competitiveness and farmers' income.

\section{MATERIAL AND METHODS}

Both primary and secondary data were used for this study. Primary data were obtained on the income levels of the exporters of four (4) purposively selected Nigeria's agricultural food exports (cowpeas, dried maize, palm oil and melon seeds).These commodities were sampled for the study because of their strategic importance in the list of Nigeria's agricultural export food items. Samples of export food items were taken with the support and guidance of Nigeria Export Promotion Council (NEPC) and National Agency for Food, Drug Administration and Control (NAFDAC).Secondary data were also used to source data and information from the various publications of the Central Bank of Nigeria, National Bureau of Statistics, Federal Ministry of Agriculture, Nigeria Customs and Excise Department, Federal Ministry of Health, and other relevant bodies. These data consisted of information on the Nigeria's major agricultural export commodities since 1980 to 2014.Emphasis was placed on the export quantities, domestic price of the export commodities and the equivalent foreign price, the destination countries of export and challenges of international trading among other issues. Information was also sought on the types of preservations, preservative chemicals being used for the export agricultural commodities and dosage levels.

For objective 1, data were collected on the price regime of four (4) of the Nigeria's major agricultural export products (cowpea, melon seed, dried maize, and palm oil) at the international markets. Then, average market prices were 
obtained for these food products ( in the UK markets) and the equivalent amounts of similar commodities at the local markets in Nigeria and these prices are compared to appreciate the level of parity (or otherwise).The closer these prices, when compared, the more competitive they are. Own-price elasticity was also computed to again observe the degree of responsiveness of the export quantities to declining market prices at the international market in the UK. Thus, according to Frank and Bernanke (2004), own-price elasticity,

$$
\varepsilon_{\mathrm{op}}=\delta \underline{\mathrm{Q} / \mathrm{Q}}
$$

$$
\begin{aligned}
& \delta \mathrm{P} / \mathrm{P} \\
& =\mathrm{P} / \mathrm{Q} * 1 / \text { Slope }
\end{aligned}
$$

Where,

$\varepsilon_{\mathrm{op}}=$ Own-price elasticity of the export commodities.

$\mathrm{Q}=\mathrm{Quantity}$ of Nigeria's export at a given time ('000 tonne) $\delta Q=$ Change in quantity of Nigeria's export at a given time ('000 tonne)

$\mathrm{P}=$ International Market Price (own) of Nigeria's export commodity at a given time $(\mathfrak{£})$

$\delta \mathrm{P}=$ Change in International Market Price (own) of Nigeria's export commodity at a given time (£)

Thus,own-price elasticity was computed for all the four (4) selected agricultural commodities to ascertain the level of reaction of the international market to changing price situations.

For objective 2, a multiple regression model was used to establish the relationship that existed among the level of quality assurance deficit of the export commodities, market competitiveness and the amount paid as tax on agricultural export commodities, among others.

$$
\text { Thus, } Y_{N}=\alpha_{0}+\beta_{1} X_{1}+\beta_{2} X_{2}+\beta_{3} X_{3}+\beta_{4} X_{4}+\beta_{5} X_{5}+e_{i}
$$

Where, $\mathrm{Y}_{\mathrm{N}}$ is the annual farm income of the exporter, $\mathrm{X}_{1}=$ Level of quality assurance deficit $(\mathrm{mg} / \mathrm{kg})$.Quality assurance deficit was captured by the difference between the estimated quantities of pesticide residues found in samples of selected food items which were prepared for export to international market (in UK) and the acceptable maximum residue limit of $0.01 \mathrm{mg} / \mathrm{kg}$. These samples were collected with the assistance of Nigeria Export Promotion Council (NEPC), Lagos, Nigeria.

$\mathrm{X}_{2}=$ Level of market competitiveness for selected Nigeria's internationally- traded agricultural export commodities (i.e. cowpea, melon seed, dried maize and palm oil) (in $£$ ).

Basically, market price competitiveness measures the level of equality/ parity (or otherwise) between international (UK) market prices of the Nigeria's agricultural export food items and the prices of similar items in the Nigerian market.

$\mathrm{X}_{3}=$ Tax paid on Export commodity (Naira)

$\mathrm{X}_{4}=$ Annual Output of Export Commodity ( tonnes)

$\mathrm{X}_{5}=$ Government Policy on Export Commodity (Dummy: If favourable to export $=1$, if otherwise $=0$ )

$e_{i}=$ Stochastic error term, which is random in behaviour.
$\mathrm{N}=$ Number of agricultural commodity exporters which is equal to 200 .

This model was used to run the analysis separately for each of the four (4) selected agricultural export commodities listed above.

\section{RESULTS AND DISCUSSION}

International market for Nigeria's export commodities continue to vary in reaction to changing market prices and consumer preferences which is often reflected by the direction of consumer demand for the commodities. Basically, at the local level, the market demand for most agricultural commodities is often high (especially during off-season), even when prices are significantly rising (high elasticity).This is a common market trend in most developing economies where there are limited storage facilities and low level of agroprocessing technologies which could add values to harvested farm produce. Again at the international level, the demand for these commodities was highly elastic between 109801992 when the exporters were observing the basic safety regulations governing the sales of the commodities. However, there was a sharp decline in the elasticity of demand for these commodities when less attention was paid to the observance of the basic safety precautions on agricultural exports by the Nigerian exporters. From Table 1 below, it is indicated that own -price elasticity values drastically declined for all the export commodities between 2004-2014 (compared with the previous years) because the demand for the selected Nigerian agricultural exports dropped at the international (UK) market. This development was largely due to the rejection of many of the nation's agricultural export commodities by the UK market as a result of allegation of non-compliance with the regulations on standards and international best practices on food storage/ preservation techniques, especially in the past one decade.

Table 1: Determination of Own-Price Elasticity for Nigeria's Export Commodities

\begin{tabular}{|l|l|l|l|}
\hline \multirow{2}{*}{ Export Commodity } & \multicolumn{3}{|l|}{ Year/Own-Price Elasticity (\%) $\varphi$} \\
\cline { 2 - 4 } & $1980-1992$ & $1993-2003$ & $2004-2014$ \\
\hline Cowpea & 124.6 & 66.4 & 34.6 \\
\hline Dried Maize & 118.3 & 58.3 & 43.1 \\
\hline Melon Seed & 106.4 & 67.6 & 22.4 \\
\hline Palm Oil & 122.6 & 45.7 & 18.3 \\
\hline
\end{tabular}

$\varphi$ Elasticity, which is the measure of the percentage change in quantity demanded expressed in relation to the percentage change in price of the commodity, could be measured in percentages (Please see Timothy Taylor and Steven A.Greenlaw (2014:Principles of Macroeconomics.Pp105-124)).

Source:Nigeria Export Promotion Council,(NEPC),Lagos, Nigeria.

Between 1980 and 2014, there was a mere marginal increase in the quantities of agricultural export commodities that were produced domestically in Nigeria (Table 2).The least yearly increase was observed in the case of palm oil while maize recorded the highest. The use of traditional farming technologies, poor storage/preservation techniques, 
low-yielding production technology and largely aged farming population were responsible for the generally low output levels of the major export commodities in Nigeria. On the whole, only about 35 per cent of the official production output was exported abroad (Table 2).These development had negative implications on the general income level of the farming households.

Table 2: Profile of selected Nigeria's agricultural export commodities (1980-2014)

\begin{tabular}{|c|c|c|c|c|c|c|}
\hline \multirow[t]{2}{*}{$\begin{array}{l}\text { Export } \\
\text { Commod- } \\
\text { ity }\end{array}$} & \multicolumn{3}{|c|}{$\begin{array}{l}\text { Year /Average Yearly Pro- } \\
\text { duction level in metric tonne }\end{array}$} & \multicolumn{3}{|c|}{$\begin{array}{l}\text { Year/Average Annual Export } \\
\text { Quantity1 (metric tonne ) }\end{array}$} \\
\hline & $\begin{array}{l}1980- \\
1992\end{array}$ & $\begin{array}{l}1993- \\
2003\end{array}$ & $\begin{array}{l}2004- \\
2014\end{array}$ & $\begin{array}{l}1980- \\
1992\end{array}$ & $\begin{array}{l}1993- \\
2003\end{array}$ & $\begin{array}{l}2004- \\
2014\end{array}$ \\
\hline Cowpea & 3669.6 & 4210.7 & 4328.3 & 1284.36 & 1473.75 & 1514.91 \\
\hline $\begin{array}{l}\text { Dried } \\
\text { Maize }\end{array}$ & 8527.9 & 8685.1 & 9503.4 & 2984.77 & 3039.79 & 3326.19 \\
\hline $\begin{array}{l}\text { Melon } \\
\text { Seed }\end{array}$ & 421.1 & 450.1 & 479.4 & 147.39 & 157.54 & 167.79 \\
\hline Palm Oil & 161.5 & 172.7 & 187.0 & 56.53 & 60.45 & 65.45 \\
\hline
\end{tabular}

Source:National Bureau of Statistics, NBS,Lagos, Nigeria,2015.

${ }^{1}$ Only about 35 per cent of the official yearly output was exported.

The level of market acceptability and consumer preference for good is often measured by the price consumers are willing to pay for such commodities, particularly at the international market level where the Nigerian export commodities are in strong market competition with other commodities from other sources. Thus, the average domestic market price (per tonne) was estimated and then compared with the international (UK) prices of the selected export commodities, using the average foreign exchange rate of the Nigerian local currency,(Naira) to the US Dollar (Table 3). Between year 2000 and 2008, it was shown that the domestic prices of the export commodities were highly competitive as their local prices were very close and sometimes higher than international prices.However,the reverse was the case between year 2009 and 2014, as the domestic prices of the Nigerian export commodities declined and the demand for them dropped hence they could not favourably compete with their international market prices (Table 3). A huge quantities of the export commodities were again rejected at the international market largely due to alleged compromised qualities. The US Dollars equivalent values of these commodities were higher than the international prices. This again indicated that there was no parity price 2 especially for cowpea, dried maize, and palm oil in the last one decade.Thus, many exporter farmers were discouraged from exporting their commodities and were therefore left with option of patronizing the Nigerian local markets. This led to a decline in the sale of farm produce and a reduction in the general household level of many
Nigerian farmers.

Table 3: Market Price Competitiveness of selected Nigeria's agricultural export commodities.

\begin{tabular}{|l|c|c|c|c|c|c|}
\hline \multirow{2}{*}{$\begin{array}{l}\text { Export } \\
\text { Commodity }\end{array}$} & \multicolumn{3}{|c|}{$\begin{array}{c}\text { Year /Average Domestic } \\
\text { Market Price per metric tonne } \\
\text { (Naira) }\end{array}$} & \multicolumn{3}{|c|}{$\begin{array}{c}\text { Year /Average International } \\
\text { Price per metric tonne } \\
\text { (Dollars) }\end{array}$} \\
\hline & $\begin{array}{c}2000- \\
2003\end{array}$ & $\begin{array}{c}2004- \\
2008\end{array}$ & $\begin{array}{c}2009- \\
2014\end{array}$ & $\begin{array}{c}2000- \\
2003\end{array}$ & $\begin{array}{c}2004- \\
2008\end{array}$ & $\begin{array}{c}2009- \\
2014\end{array}$ \\
\hline Cowpea & $\begin{array}{c}49,370.0 \\
(\$ 509.81)\end{array}$ & $\begin{array}{c}56,045.0 \\
(\$ 449.62)\end{array}$ & $\begin{array}{c}62,717.2 \\
(\$ 403.53)\end{array}$ & 97.6 & 101.3 & 615.85 \\
\hline $\begin{array}{l}\text { Dried } \\
\text { Maize }\end{array}$ & $\begin{array}{c}28,054.2 \\
(\$ 289.69)\end{array}$ & $\begin{array}{c}36,782.3 \\
(\$ 295.08)\end{array}$ & $\begin{array}{c}47,921.0 \\
(\$ 308.33)\end{array}$ & 42.8 & 65.9 & 342.37 \\
\hline Melon Seed & $\begin{array}{c}22,134.0 \\
(\$ 228.56)\end{array}$ & $\begin{array}{c}29,006.0 \\
(\$ 252.69)\end{array}$ & $\begin{array}{c}34,974.7 \\
(\$ 225.03)\end{array}$ & 22.3 & 34.9 & 118.7 \\
\hline Palm Oil & $\begin{array}{l}88,300 \\
(\$ 911.81)\end{array}$ & $\begin{array}{c}110,151.1 \\
(\$ 883.68)\end{array}$ & $\begin{array}{c}133,003.6 \\
(\$ 855.77)\end{array}$ & 121.4 & 147.5 & 920.89 \\
\hline $\begin{array}{l}\text { Mean Exch. } \\
\text { rate of } \\
\text { Naira/US\$ }\end{array}$ & 96.84 & 124.65 & 155.42 & & & \\
\hline
\end{tabular}

Source:National Bureau of Statistics, NBS, Lagos, Nigeria, 2015

Note: All values in parentheses were the domestic market prices of the selected Nigeria's agricultural commodities in US Dollars.

${ }^{2}$ Parity price provides the farm products the same purchasing power per unit for goods and services used in both production and family consumption relative to prices that prevailed in the base year. It often reflects the concern of government about the purchasing power of the farmers. These are popular parameters by which many developed economies have shown concerns about the purchasing power of their farmers.

The level of market competitiveness and quality assurance of the farm output often determine the amount of income farmers realise at the end of the farming season. This is so because the farmers have to present their farm products at the international market where these products compete with other commodities from various sources. Hence, the need to observe and comply with the international best practices on standards and grading of these agricultural commodities, especially with respect to the use of chemical as preservatives. These farmers therefore need to mind the types, quantities and methods of preservatives being used for their farm products so that the quality of these products is assured in the market; since this has a serious implication on market prices. The most common types of chemicals being used for the preservation of farm products include Gamma BHC/lindane,Malathion,Iodafenphos (such as Nuvanol and Elocril),Dichlorvos and synthetic pyrethroid (e.g. permethrin), among others.

For all the four (4) agricultural export commodities, the estimated values of parameter co-efficient estimates (Table 4) indicated that the level of market competitiveness and quality assurance deficit were significant determinants of the annual farm income of the exporters of the agricultural commodities.Specifically, for cowpea, melon seed and palm oil the two parameters were significant at 1 per cent level .In the case of dried maize, quality assurance deficit was 
found to be a significant parameter at 1 per cent while market competitiveness was significant at 5 per cent level. In addition,tax paid on export commodity, annual output level and government policy on exports were also found to be significant at various levels. However,tax payment and government policy were not significant in the case of dried maize and cowpea respectively. High values of adjusted R2 ,which varied between 0.67 (for melon seed) and 0.92 (for palm oil) indicated the correctness and exactness of the specification of the regression model as stated in equation (3). High values for Log likelihood function, which ranged between 233.04 (for cowpea) and 771.53 (for melon seed) again corroborated the feeling that the regression model had a reasonably acceptable level of reliability.

Table 4: Multiple Regression Analysis indicating relationship between

\begin{tabular}{|c|c|c|c|c|c|c|c|c|}
\hline \multirow[b]{2}{*}{ Variable } & \multicolumn{2}{|c|}{ COWPEA } & \multicolumn{2}{|c|}{ MELON SEED } & \multicolumn{2}{|c|}{ DRIED MAIZE } & \multicolumn{2}{|c|}{ PALM OIL } \\
\hline & $\begin{array}{c}\text { Parameter } \\
\text { Co-efficient }\end{array}$ & T-value & $\begin{array}{l}\text { Parameter } \\
\text { Co-efficient }\end{array}$ & T-value & $\begin{array}{l}\text { Parameter } \\
\text { Co-efficient }\end{array}$ & T-value & $\begin{array}{l}\text { Parameter } \\
\text { Co-efficient }\end{array}$ & T-value \\
\hline Constant term & $\begin{array}{c}237.92 * * * \\
(73.89)\end{array}$ & 3.22 & $\begin{array}{l}45.54 * * * \\
(7.18)\end{array}$ & 6.34 & $\begin{array}{l}18.46^{* * *} \\
(0.78)\end{array}$ & 23.73 & $\begin{array}{l}26.56 \\
(21.25)\end{array}$ & 1.25 \\
\hline $\begin{array}{l}\text { Quality Assurance Deficit } \\
\left(\mathrm{X}_{1}\right)\end{array}$ & $\begin{array}{c}15.36^{* * * *} \\
(1.80)\end{array}$ & 8.54 & $\begin{array}{c}22.45^{* * * *} \\
(8.47)\end{array}$ & 2.65 & $\begin{array}{c}82.21 * * * \\
(30.11)\end{array}$ & 2.73 & $\begin{array}{c}34.54 * * * \\
(2.43)\end{array}$ & 14.23 \\
\hline $\begin{array}{l}\text { Market Competitiveness } \\
\left(\mathrm{X}_{2}\right)\end{array}$ & $\begin{array}{c}243.32 * * * \\
(46.52)\end{array}$ & 5.23 & $\begin{array}{c}24.31 * * * \\
4.29)\end{array}$ & 5.67 & $\begin{array}{c}36.45^{* *} \\
(19.81)\end{array}$ & 1.84 & $\begin{array}{l}835.31 * * * \\
(69.44)\end{array}$ & 12.03 \\
\hline $\begin{array}{l}\text { Tax on Export Commod- } \\
\text { ity }\left(\mathrm{X}_{3}\right)\end{array}$ & $\begin{array}{l}145.9 * * \\
(86.83)\end{array}$ & 1.67 & $\begin{array}{c}331.95^{* * *} \\
(80.57)\end{array}$ & 4.12 & $\begin{array}{c}54.2 \\
(49.72)\end{array}$ & 1.09 & $\begin{array}{c}134.10^{* * *} \\
(43.12)\end{array}$ & 3.11 \\
\hline Annual Output level $\left(\mathrm{X}_{4}\right)$ & $\begin{array}{l}43.8^{* * *} \\
(11.01)\end{array}$ & 3.98 & $\begin{array}{c}121.9 * * * \\
(49.76)\end{array}$ & 2.45 & $\begin{array}{l}51.9 * * * \\
(17.96)\end{array}$ & 2.89 & $\begin{array}{l}212.6^{* * * *} \\
(40.34)\end{array}$ & 5.27 \\
\hline Govt. Policy $\left(\mathrm{X}_{5}\right)$ & $\begin{array}{c}88.3 \\
(70.64)\end{array}$ & 1.25 & $\begin{array}{c}332.80 * * * \\
(69.62)\end{array}$ & 4.78 & $\begin{array}{l}72.9 * * * \\
(10.53)\end{array}$ & 6.92 & $\begin{array}{c}227.5 * * * \\
(78.18)\end{array}$ & 2.91 \\
\hline Chi square & 65.52 & - & 71.39 & - & 49.32 & - & 85.03 & - \\
\hline Adjusted $\mathrm{R}^{2}$ & 0.74 & - & 0.67 & - & 0.78 & - & 0.92 & - \\
\hline Log likelihood function & 233.04 & - & 771.53 & - & 439.20 & - & 628.91 & - \\
\hline
\end{tabular}

Farmer's income and determinant variables Dependence variable $=$ Annual farm income of the exporter $* * *=$ Significant at $1 \%$ level $\quad * *=$ Significant at $5 \%$ level

Figures in parentheses are standard errors.

This study has investigated the effect of quality assurance deficit and market competitiveness on the household income of the Nigerian agricultural commodity exporters. Many of the export commodities now fail the quality assurance test hence they cannot sustain their competition in the international markets which also display many quality products. The immediate implication of this development is that many of the Nigeria's export commodities were restricted from the UK markets. This has caused a huge decline to the annual income level of the Nigerian farm producers who often export their products. But all hopes are not lost, especially if these farmers are able to observe and comply with the global best practices on the use of chemical preservatives for their exported farm products. This will reduce the level of chemical residues which are considered injurious to the health of the consumers of these food items. The local (traditional) methods of product storage and preservation which do not involve the use of chemical substances could be adopted by the farmers as alternative ways of protecting the qualities of farm produce. With this, the Nigerian agricultural export commodities will again be accepted and remain competitive at the international markets. This will bring a higher income to the Nigerian agricultural commodity exporters and ultimately improve the general income levels of the farming households in Nigeria.

\section{ACKNOWLEDGEMENTS:}

The author is grateful for the support received from the Nigeria Export Promotion Council ( NEP C ), L a g o s, National Agency for Food, Drug A d m in is tration and Control (NAFDAC), Central Bank of Nigeria (CBN) and National Bureau of Statistics (NBS).Kind permission granted by the Federal Ministry of Agriculture, Nigeria Customs \& Excise Department and Federal Ministry of Health to access vital information on export commodities is also noted with high respect. 
Development,University of Ibadan,Nigeria.88-92.

CBN (2006). Annual Report and Statement of Accounts.Central Bank of Nigeria.34-45.

CBN,(2015). Central Bank of Nigeria.Quarterly bulletin.17-19.

Frank,R.H.and Bernake,B.S. (2004):Principles of Economics. Second Edition.Chapt.4.91-115.

Helleiner,G.K,(1988) The marketing board system and alternative arrangements for commodity

marketing in Nigeria, in : Readings in Agricultural Marketing,Adekanye,T.O.(ed). Longman

Nigeria.71-72.

NBS (2002).Nigeria Foreign Trade Summary. National Bureau of Statistics.

Central Business Area,Garki,Abuja,Nigeria.

NBS (2009). Annual Abstract of Statistics. National Bureau of Statistics. Chapter 11.Pp415-428.

NEPC,(2015).Trade Statistical Bulletin.Nigerian Export Promotion Council,Lagos, Nigeria

Olatunbosun,D. and Olayide,S.O.(1988) .Effects of the Nigerian marketing boards on the output

and income of the primary producers, in: Readings in Agricultural Marketing,Adekanye,T.O.

(ed).Longman Nigeria.78-84.

Olayemi,J.K. (1980).Food crop production by small farmers in Nigeria, in :Nigerian Small

Farmers:Problems and Prospects in Integrated Rural Deve lopment,Olayide,S.O.,Eweka,J.A.and

Bello-Osagie,V.E.(eds),Centre for Agricultural Rural and Development,University of

Ibadan, Nigeria.17-21.

Olayide,S.O. (1988). Economics of inter-state marketing of farm products:a spatial analysis of

transportation costs,in: Readings in Agricultural Marketing,Adekanye,T.O.(ed).

Longman Nigeria. 61-64

Olukosi,,J.O. and Isitor,S.U.(1990). Introduction to Agricultural Marketing and Prices:Principles

and Applications.Living Books Series,Abuja,FCT.106-113.

Timothy ,T and Steven A.G. (2014):Principles of Macroeconomics.Openstax College,Rice University,Houston Texas,USA.Pp.105-124. 